\title{
EFFECTS OF SEWAGE SLUDGE APPLICATIONS TO AGRICULTURAL SOIL ON THE BIOCHEMICAL PARAMETERS OF FABA BEAN (FABA SATIVA BERNH.), WHEAT (TRITICUM AESTIVUM L.), SPINACH (SPINACIA OLERACEA L.) AND CUCUMBER (CUCUMIS SATIVUS L.) CROPS
}

\author{
EID, E. M..$^{1,2}$ - El-BebANY, A. F. ${ }^{3 *}-$ TAHER, M. A. ${ }^{1,4}-$ AlRUMMAn, S. A. ${ }^{1}-$ HuSSAIN, A. A. ${ }^{1}-$

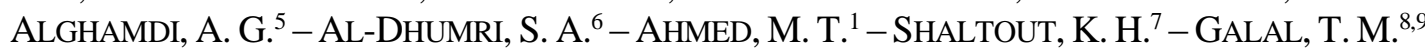 \\ ${ }^{1}$ Biology Department, College of Science, King Khalid University, Abha 61321, Saudi Arabia \\ ${ }^{2}$ Botany Department, Faculty of Science, Kafrelsheikh University, Kafr El-Sheikh 33516, Egypt \\ ${ }^{3}$ Plant Pathology Department, Faculty of Agriculture, Alexandria University, El-Shatby 21545, \\ Alexandria, Egypt \\ ${ }^{4}$ Botany Department, Faculty of Science, Aswan University, Aswan 81528, Egypt \\ ${ }^{5}$ Soil Sciences Department, College of Food and Agriculture Sciences, King Saud University, \\ P.O. Box 2460, Riyadh 11451, Saudi Arabia \\ ${ }^{6}$ Biology Department, University College of Alkhormah, Taif University, Taif 21974, Saudi \\ Arabia \\ ${ }^{7}$ Botany Department, Faculty of Science, Tanta University, Tanta 31527, Egypt \\ ${ }^{8}$ Biology Department, Faculty of Science, Taif University, Taif, Saudi Arabia \\ ${ }^{9}$ Botany and Microbiology Department, Faculty of Science, Helwan University, Cairo, Egypt \\ *Corresponding author \\ e-mail: aelbebany@yahoo.com; phone: +20-112-315-8526; fax: +20-3-592-2780
}

(Received $8^{\text {th }}$ Apr 2020; accepted 29 Jul 2020)

\begin{abstract}
This study aimed to assess the sewage sludge (SS) amendments to agricultural soil on the biochemical composition of four plants (faba bean, wheat, spinach and cucumber). The applied SS rates were $0,10,20,30,40$ and $50 \mathrm{~g} / \mathrm{kg}$ soil. Plant leaves 45 days after SS treatments were used in biochemical parameter analyses. Starch decreased in spinach from 179.34 to $41.38 \mathrm{mg} / \mathrm{g} \mathrm{DW}$ with SS treatments and increased in faba bean, wheat and cucumber at 10,20,30 and $40 \mathrm{~g} / \mathrm{kg}$ rates. Water soluble carbohydrates and total non-structural carbohydrates declined in the four plants with SS treatments. Total lipids increased in faba bean and spinach up to 41.94 and $7.89 \mathrm{mg} / \mathrm{g} \mathrm{FW}$, respectively, at the SS amendment of $50 \mathrm{~g} / \mathrm{kg}$, while in wheat and cucumber the increase was detected only at 40 and $50 \mathrm{~g} / \mathrm{kg}$ rates. In spinach, the accumulation of proline started at SS treatment of $10 \mathrm{~g} / \mathrm{kg}$, while, for wheat and cucumber the increase of proline was started at $20 \mathrm{~g} / \mathrm{kg}$ SS. The highest proline accumulation was $0.96 \mathrm{mg} / \mathrm{g} \mathrm{FW}$ in spinach at $50 \mathrm{~g} / \mathrm{kg}$ SS rate. SS did not affect phenol content in faba bean and spinach with any treatment, whereas, the phenol declined in wheat and cucumber.
\end{abstract}

Keywords: carbohydrates, economic plants, environmental pollution, phenol, proline 


\section{Introduction}

Application of sewage sludge (SS) in the agricultural sector as soil fertilizers is in several countries (Singh and Agrawal, 2008 and 2010). The municipal SS is a source of macro- and micro-nutrients for crops cultivated in SS amended agricultural soil (Ahmed et al., 2010; Abdul Khaliq et al., 2017). Soil amendment with SS at different rates has improved the growth and yield of several crops including faba bean (Faba sativa Bernh.), wheat (Triticum aestivum L.), spinach (Spinacia oleracea L.) and cucumber (Cucumis sativus L.) (Eid et al., 2017a, b, 2018, 2019). Bioaccumulation and translocation of certain heavy metals in tissues of crops cultivated in soil amended with sewage sludge were analyzed in several plants (Kabata-Pendias, 2011; Bourioug et al., 2014; Eid et al., 2020a, b).

Chemical constituents of plants grown in soils amended with SS play a vital role in plant physiology as biochemical responses to abiotic stresses (Sharma et al., 2018). Carbohydrates are major components in plant tissues since they are related to the primary metabolism. Carbohydrates content has been monitored in several crops when cultivated in SS amended soils (Han et al., 2004). Elevation of nitrogen, phosphorus and potassium content and other macro-nutrients in plants grown in agricultural soil supplemented with SS has been reported in several studies (Hue, 1988; Bourioug et al., 2014; Kępka et al., 2016). Proline content has been investigated wildly as protectant to environmental toxicity stress in many crops (Boudjabi et al., 2015). Phenolic compounds in plants such as Beta vulgaris and Albizia lebbek were reported in response irrigation with municipal waste water and heavy metal toxicity (Tripathi and Tripathi, 1999; Singh and Agrawal, 2010). Biochemical composition analyses of the four economic plants under investigation is essential since leaves of spinach, seeds of faba bean, grains of wheat and fruits of cucumber are used for human consumption and the hay produced from wheat and faba bean is used for animal feeding.

The objective of the current investigation is to determine the effect of SS application to agricultural soils on the content of starch, water soluble carbohydrates (WSC), total non-structural carbohydrates (TNC), total lipids, proline and phenol in leaves of faba bean, wheat, spinach and cucumber plants.

\section{Materials and methods}

\section{Soil-sewage sludge treatments}

Four plant species, namely, faba bean (Faba sativa), wheat (Triticum aestivum), spinach (Spinacia oleracea) and cucumber (Cucumis sativus) were used to assess the effects of soil amendments with SS on biochemical composition of leaves of the tested crops. The rates of soil-sewage sludge amendments were zero (control), 10, 20, 30, 40, and $50 \mathrm{~g} \mathrm{SS} / \mathrm{kg}$ soil. The detailed analysis the physic-chemical properties of the applied SS used in the current study was previously performed; salinity 2.07; $\mathrm{pH} 6.38$; organic matter $65.1 \%$; the heavy metals concentrations were Cd $(1.17 \mathrm{mg} / \mathrm{kg})$, Co $(27.9 \mathrm{mg} / \mathrm{kg})$, $\mathrm{Cr}(179.1 \mathrm{mg} / \mathrm{kg}), \mathrm{Cu}(162.6 \mathrm{mg} / \mathrm{kg}), \mathrm{Fe}(25.4 \mathrm{mg} / \mathrm{g}), \mathrm{Mn}(595.7 \mathrm{mg} / \mathrm{kg}), \mathrm{Ni}$ (138.7 mg/kg), Pb (671.2 mg/kg) and Zn (667.6 mg/kg) (Eid et al., 2017a, b, 2018, 2019).

\section{Plant materials and growth conditions}

The broad bean, wheat, spinach (Superdane 7 Star, F1 Hybrid, Denmark) and cucumber seeds were obtained from local markets in Abha City. The seeds were planted 
in plastic pots filled with $4 \mathrm{~kg}$ of each respective SS-soil mixture. Three biological replicates were used. The broad bean and wheat were grown for 80 days, while, spinach and cucumber were grown for 50 days. Figure 1 shows the experimental setup of the four plants grown in pots represent the rates of sewage sludge-soil amendment rates. The greenhouse conditions were natural day/night regime and the plants were watered when needed (Eid et al., 2017a, b, 2018, 2019).
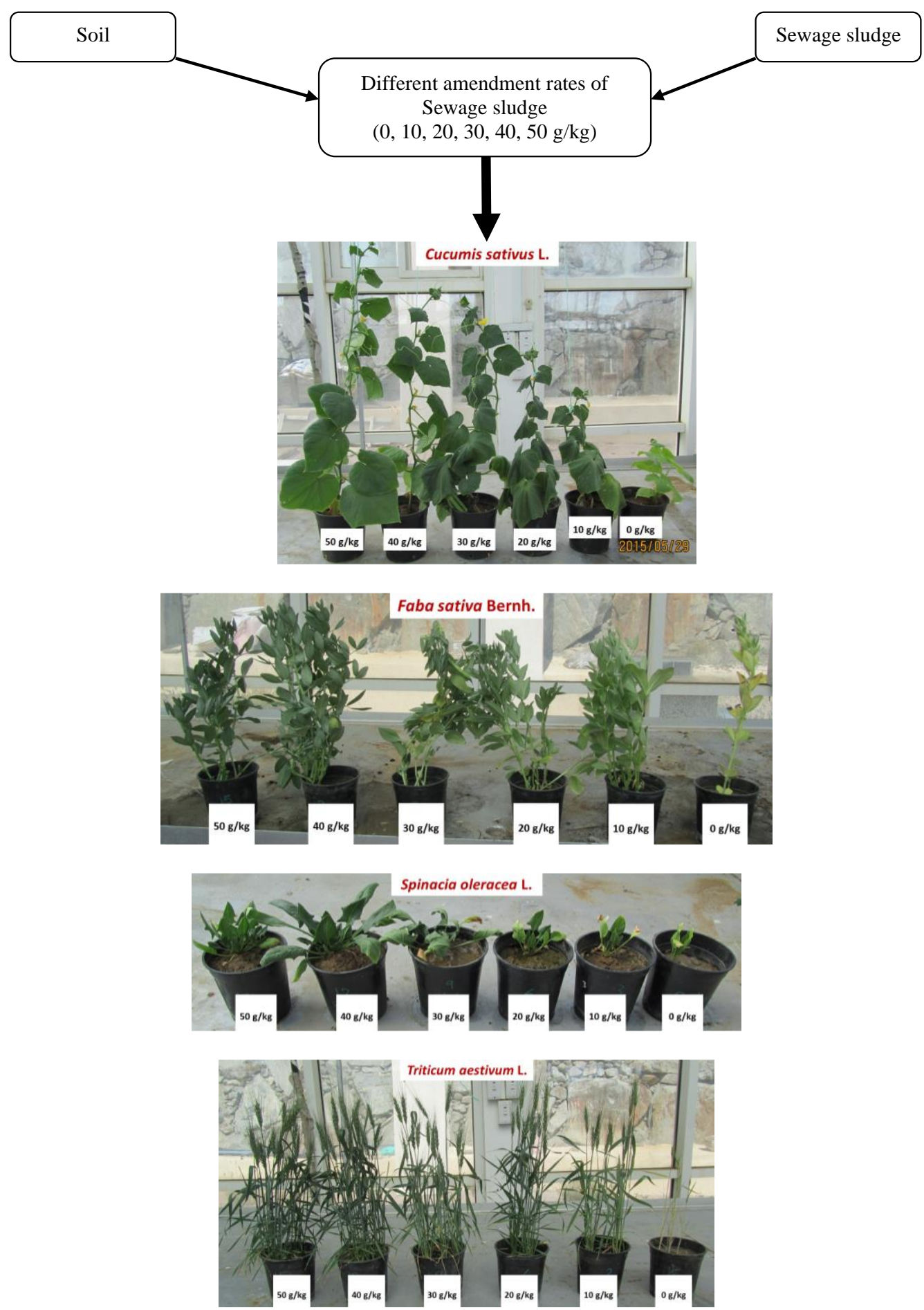

Figure 1. A demonstration of the experiment steps with the four plants in pots represents the treatments of sewage sludge-soil amendment rates 


\section{Biochemical analyses}

Fully expanded fresh leaves from all the replicates for four species were sampled manually at 45 days, first washed under the running water and some kept in freezer at $-20^{\circ} \mathrm{C}$ for further estimation of total lipids, proline and phenol. Some leaves were dried in the oven at a temperature of $60{ }^{\circ} \mathrm{C}$. Dried leaf materials were ground using a metalfree plastic mill into particles less than $0.4 \mathrm{~mm}$ for carbohydrate analysis. Total lipids concentration was measured following the method of Byreddy et al. (2016). Proline concentration was measured by the method of Bates et al. (1973). Total phenol concentration was measured following the method of Bray and Thorpe (1954). Watersoluble carbohydrates (WSCs) were extracted from $0.25 \mathrm{~g}$ of ground material with hot distilled water, while total non-structural carbohydrates (TNCs) were extracted from another $0.25 \mathrm{~g}$ of ground material using diluted $\mathrm{H}_{2} \mathrm{SO}_{4}$ following the method of Smith et al. (1964). WSC and TNC concentrations (mg/g DW) in the extracted solutions were measured by spectrophotometry using the phenol- $\mathrm{H}_{2} \mathrm{SO}_{4}$ colorimetric method as described in Granéli et al. (1992), where the standard was glucose. The starch concentration was calculated according to Equation 1:

$$
\text { Starch }(\mathrm{mg} / \mathrm{g} \mathrm{DW})=0.9 \times(\mathrm{TNC} \text { conc. }(\mathrm{mg} / \mathrm{g} \mathrm{DW})-\text { WSC conc. }(\mathrm{mg} / \mathrm{g} \mathrm{DW}))
$$

where TNC is the total non-structural carbohydrates and WSC is the water-soluble carbohydrates

\section{Data analyses}

Because absorption, accumulation and tolerance to heavy metals vary between different crops and at different levels of SS amendments (see Eid et al., 2017b) and hence heavy metal effects on the concentrations of total lipids, proline, phenol, WSC, TNC, and starch concentrations may vary between these different crops. Therefore, significant differences in the total lipids, proline, phenol, WSC, TNC, and starch concentrations between the spinach, cucumber, faba bean and wheat plants grown in soils amended with different rates of SS were evaluated using a two-way analysis of variance (ANOVA). The data were examined for their homogeneity of variance and normality of distribution, and when necessary, the data were log-transformed before a two-way ANOVA was performed. Significant difference between means among the five SS treatments were identified using the Tukey's HSD test at $p<0.05$. Statistica 7.1 was used to process all of the statistical analyses (Statsoft, 2007).

\section{Results and discussion}

Application of sewage sludge to the agricultural soil has been reported to increase the growth and biomass of several crops. The growth of the four plants used in the current study was promoted when grown in soil amended with SS (Eid et al., 2017a, b, $2018,2019)$. The biochemical parameters of leaves from the treated plants were determined. Figure 2 illustrates the effect of SS treatments on starch content $(\mathrm{mg} / \mathrm{g}$ DW) in faba bean, wheat, spinach and cucumber leaves. Spinach showed the highest content of starch as compared to faba bean, wheat and cucumber, however, the treatment with SS decreased the starch concentration significantly in spinach leaves with all SS amendment treatments from 179.34 to $41.38 \mathrm{mg} / \mathrm{g}$ DW. For faba bean there 
was an increase in starch concentration at all SS treatments with obvious significant increase at amendments rates of 10 and $20 \mathrm{~g} / \mathrm{kg}$ with concentrations of 73.07 and $89.56 \mathrm{mg} / \mathrm{g} \mathrm{DW}$, respectively. Starch concentration in leaves of wheat and cucumber increased at treatment rates of $10,20,30$ and $40 \mathrm{~g} / \mathrm{kg}$ with the highest concentrations at SS treatment of $20 \mathrm{~g} / \mathrm{kg}$ with $100.42 \mathrm{mg} / \mathrm{g}$ DW of wheat and $95.86 \mathrm{mg} / \mathrm{g} \mathrm{DW}$ of cucumber then starch concentrations were declined significantly at the highest SS treatment rate of $50 \mathrm{~g} / \mathrm{kg}$. Stimulation of carbohydrates as response to SS application has been reported in bean (Zeid and Abou El Ghate, 2007). The enhancement of starch synthesis in plants treated with sewage sludge could be a result of increasing photosynthetic pigments, i.e. chlorophyll, with the organic matter, macro- and micronutrients in SS which result in increasing of the starch biosynthesis (El-Maghraby and Gomaa, 1992).

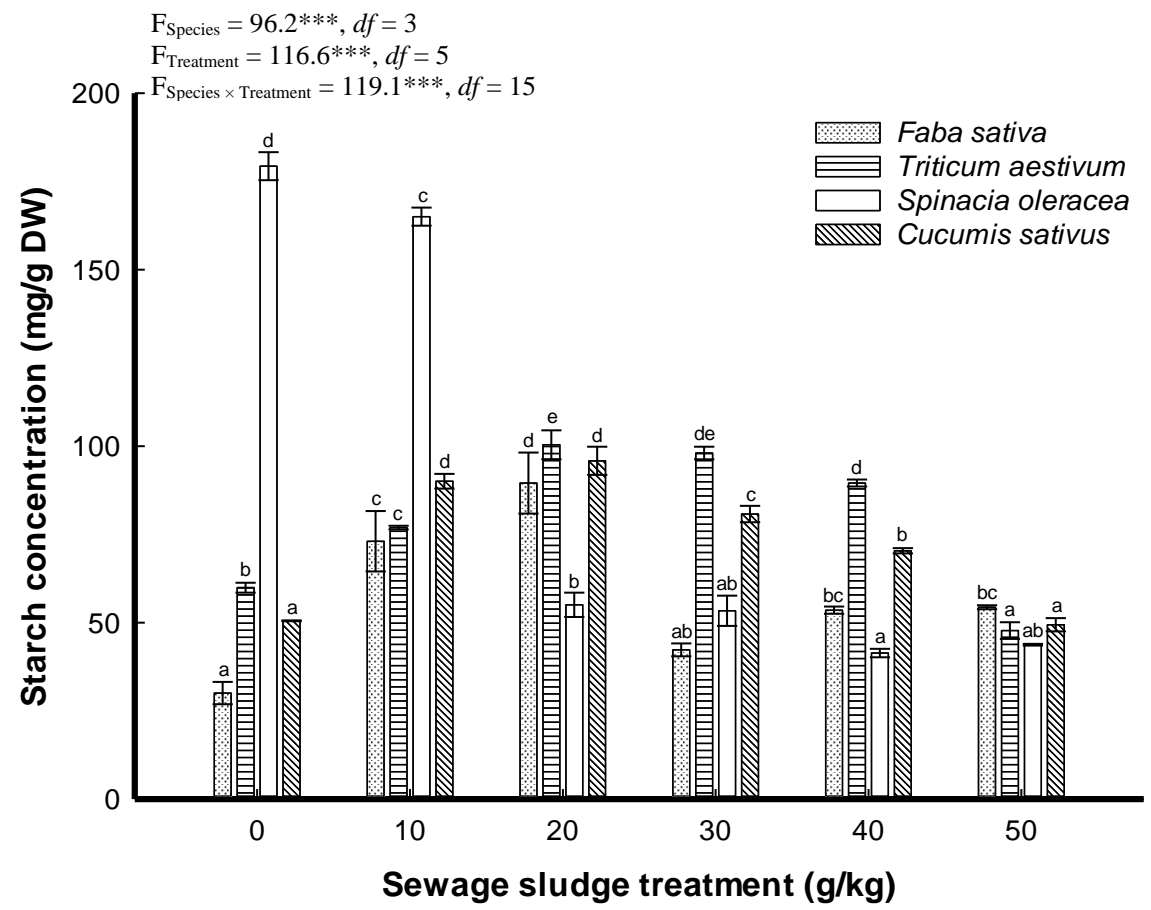

Figure 2. Starch concentration (mean \pm standard error) in leaves of the four plant species Faba sativa, Triticum aestivum, Spinacia oleracea and Cucumis sativus grown in soil amended with different sewage sludge treatment rates. Means (for each plant species) with different letters are significantly different at $p<0.05$ according to Tukey's HSD test. ***: $p<0.001$, df: degrees of freedom

The concentrations of water soluble carbohydrates (Fig. 3) and total non-structural carbohydrates (Fig. 4) were inhibited in the four plant leaves due to soil amendment with SS at all treatment rates. It has been reported that total organic carbon was increased in response to SS treatments (Abdul Khaliq et al., 2017). Soluble sugar contents in sunflower plant grown in SS amended soil were increased significantly and suggested to play role in defense mechanisms that triggered by heavy metals in the SS (Belhaj et al., 2016). In maize plants, sugars content, proline and antioxidant enzymes activity were increased when the plant irrigated with sewage water (Abdel Latef and Sallam, 2015). 


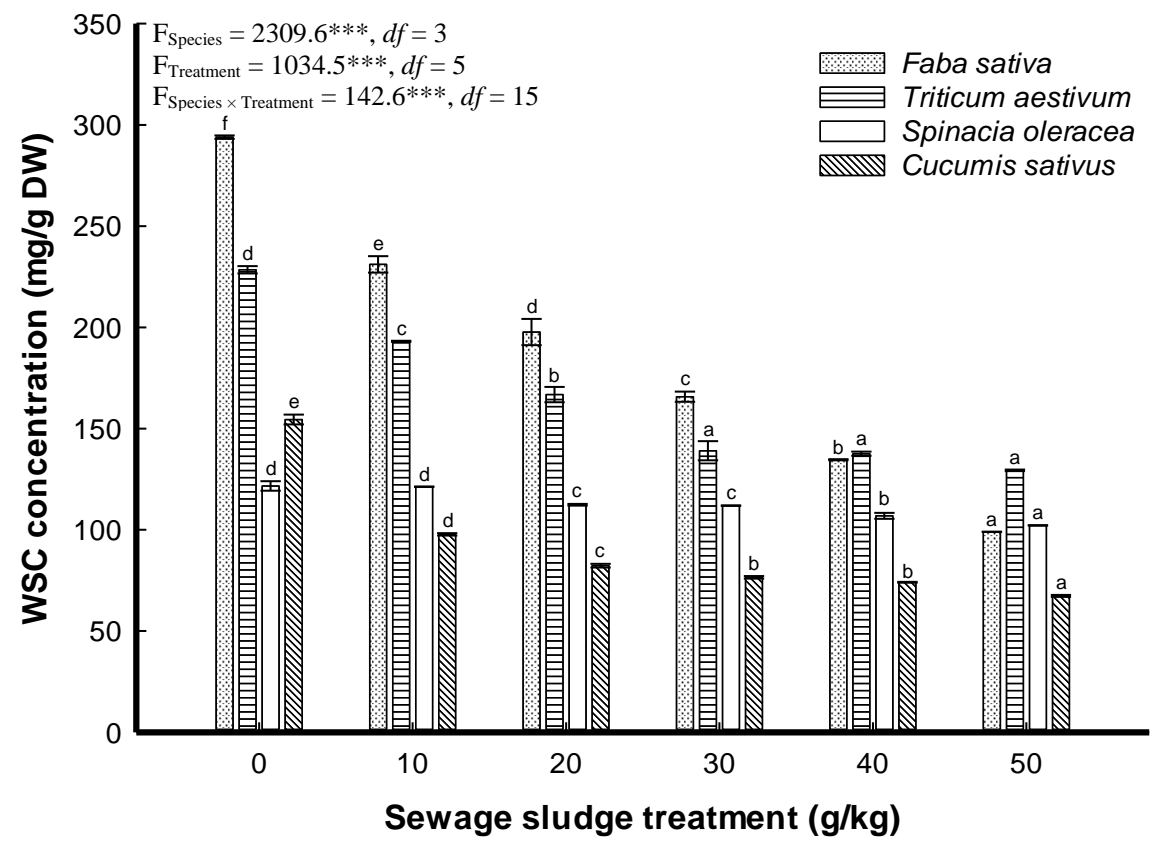

Figure 3. Water soluble carbohydrates (WSC) concentration (mean \pm standard error) in leaves of the four plant species Faba sativa, Triticum aestivum, Spinacia oleracea and Cucumis sativus grown in soil amended with different sewage sludge treatment rates. Means (for each plant species) with different letters are significantly different at $p<0.05$ according to Tukey's HSD test. $* * *: p<0.001, d f:$ degrees of freedom

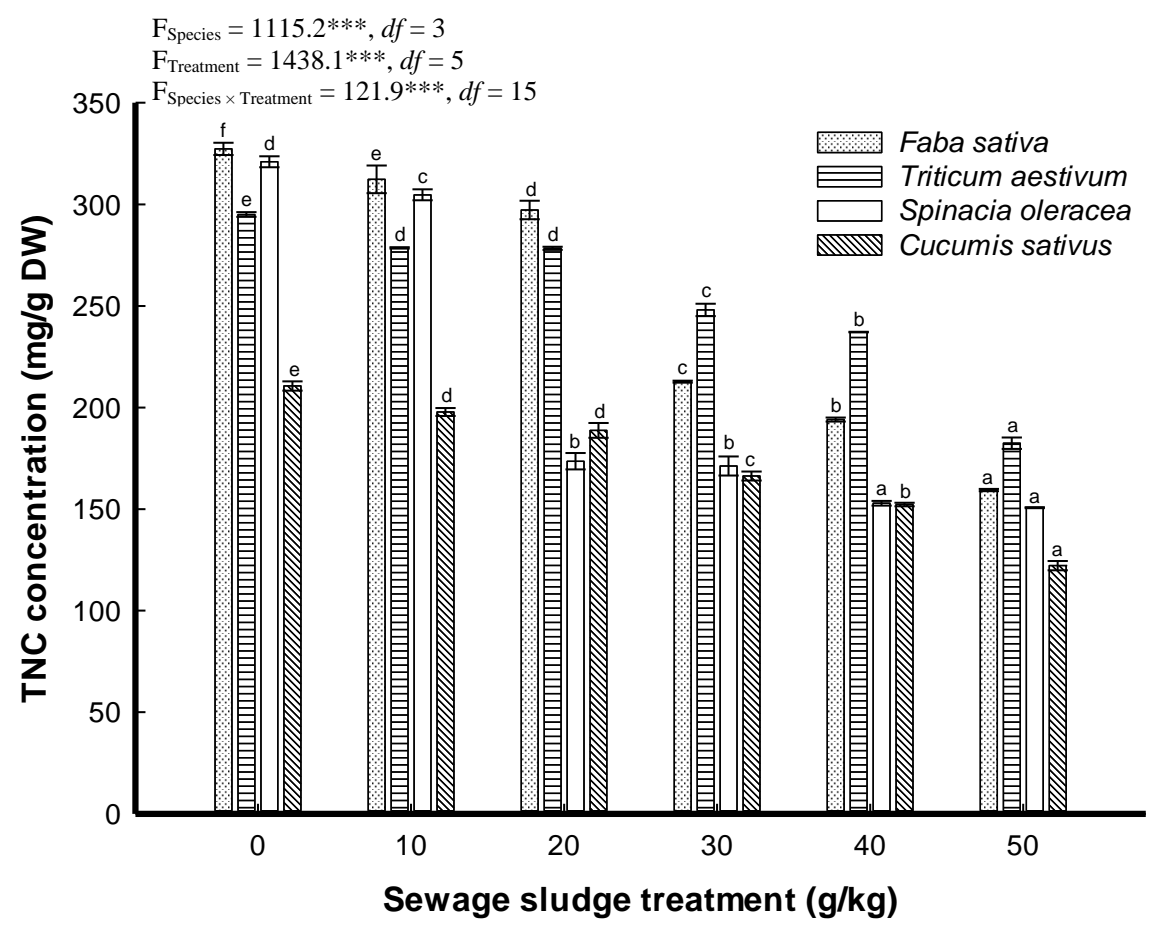

Figure 4. Total non-structural carbohydrates (TNC) concentration (mean \pm standard error) in leaves of the four plant species Faba sativa, Triticum aestivum, Spinacia oleracea and Cucumis sativus grown in soil amended with different sewage sludge treatment rates. Means (for each plant species) with different letters are significantly different at $p<0.05$ according to Tukey's HSD test. ***: $p<0.001, d f$ : degrees of freedom 
Total lipids concentrations in leaves of the four analysed plants are demonstrated in Figure 5. In both faba bean and spinach, the increase of total lipids was gradual and the significant levels were detected on SS treatment rates of $20 \mathrm{~g} / \mathrm{kg}$ and above. For the wheat and cucumber, the significant increase of total lipids content in leaves was observed only at high SS treatment rates of 40 and $50 \mathrm{~g} / \mathrm{kg}$. Increasing of lipid peroxidation and proline content has been detected in tomato seedling grown in soil amended with SS (Elloumi et al., 2016). Several studies reported detoxification processes after exposure to SS which indicated using lipid peroxide assays in plant tissues and associate that with uptake of heavy metals from SS (Wyrwicka and Urbaniak, 2016).

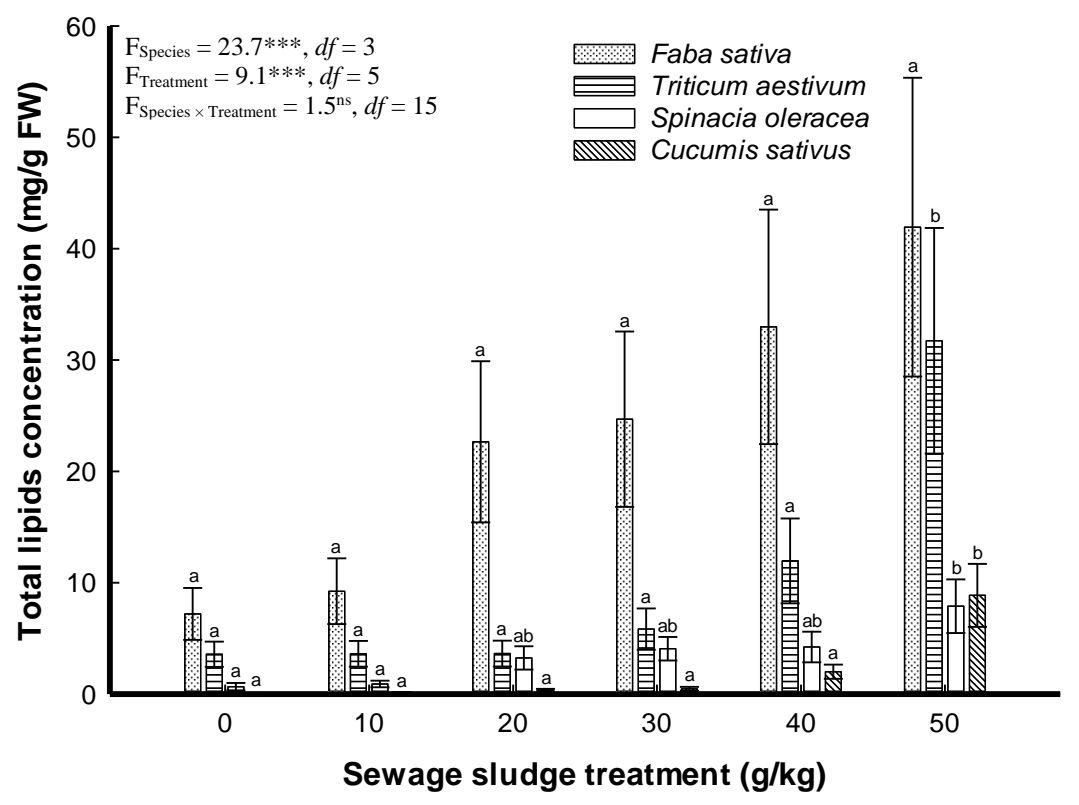

Figure 5. Total lipids concentration (mean \pm standard error) in leaves of the four plant species Faba sativa, Triticum aestivum, Spinacia oleracea and Cucumis sativus grown in soil amended with different sewage sludge treatment rates. Means (for each plant species) with different letters are significantly different at $p<0.05$ according to Tukey's HSD test. ${ }^{* * *}: p<0.001$, ns: not significant (i.e., $p>0.05$ ), $d f$ : degrees of freedom

The amino acid proline is known to be accumulated in plant tissues as response of abiotic stresses on several crops (John et al., 2009). Proline concentration in leaves of the four plants was assessed (Fig. 6). The proline concentration was in the same level in control plants. In faba bean, the increase of proline was slight at all SS treatment rates. The application of SS amendment rates stimulated the biosynthesis and accumulation of proline in leaves of wheat, spinach and cucumber plants. In spinach, the significant increase level of proline started at SS treatment of $10 \mathrm{~g} / \mathrm{kg}$ with concentration of $0.39 \mathrm{mg} / \mathrm{g} \mathrm{FW}$ to $0.96 \mathrm{mg} / \mathrm{g} \mathrm{FW}$ at SS treatment $50 \mathrm{~g} / \mathrm{kg}$, while, in case of wheat and cucumber the significant increase of proline was detected at 20,30, 40 and $50 \mathrm{~g} / \mathrm{kg} \mathrm{SS}$ treatment rates. It has been reported that proline may play a role in protection of enzymes, cellular organelles and adjust the osmotic pressure of plant cells under environmental stress conditions (Dhir et al., 2004; Tantrey and Agnihotri, 2010). The stress-protective role of proline was documented in wheat plants treated with cadmium (Asgharipour et al., 2011). Proline was accumulated in wheat plants cultivated in desert reclaimed soil amended with SS (Mazen et al., 2010). 


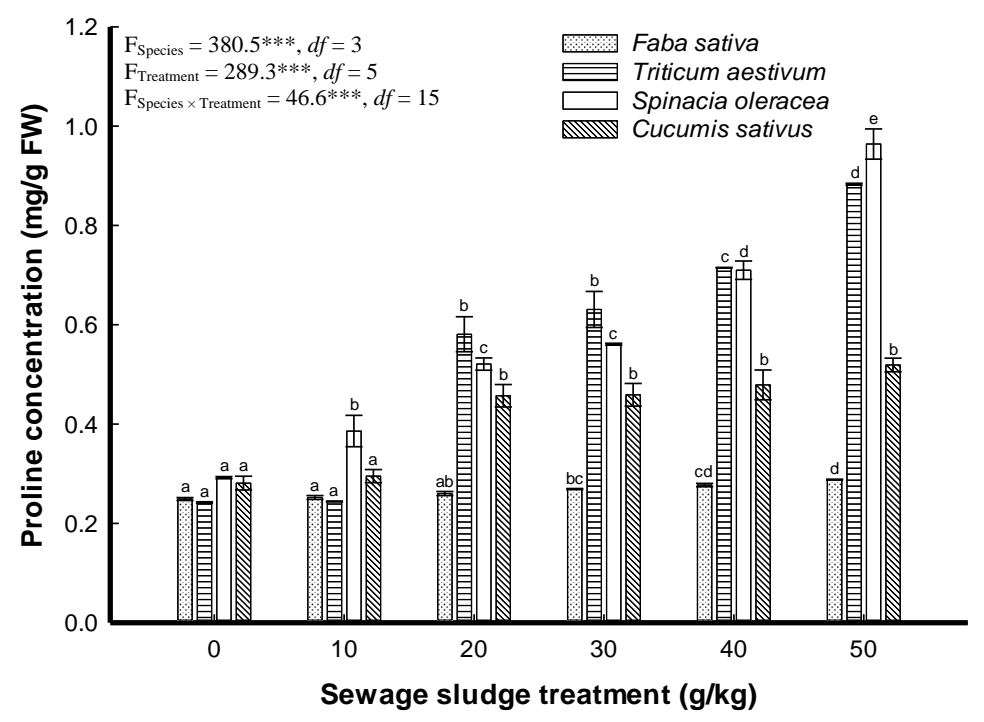

Figure 6. Proline concentration (mean \pm standard error) in leaves of the four plant species Faba sativa, Triticum aestivum, Spinacia oleracea and Cucumis sativus grown in soil amended with different sewage sludge treatment rates. Means (for each plant species) with different letters are significantly different at $p<0.05$ according to Tukey's HSD test. ${ }^{* *}: p<0.001$, $d f$ : degrees of freedom

Figure 7 presents the relationship between SS treatment rates and phenol concentrations in leaves of faba bean, wheat, spinach and cucumber. SS amendment did not affect the phenol content in faba bean and spinach at all treatment rates. On the other hand, phenol concentration in leaves of wheat and cucumber was declined with SS treatment. The decline was at rates of 40 and $50 \mathrm{~g} / \mathrm{kg}$ in wheat and was at all SS treatment rates in case of cucumber plant.

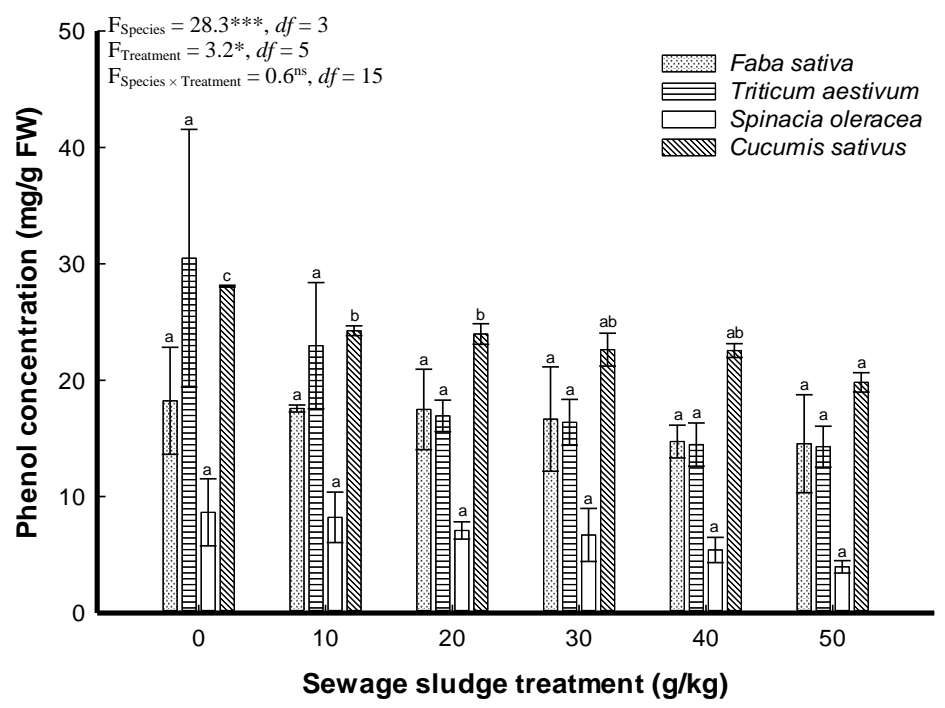

Figure 7. Phenol concentration (mean \pm standard error) in leaves of the four plant species Faba sativa, Triticum aestivum, Spinacia oleracea and Cucumis sativus grown in soil amended with different sewage sludge treatment rates. Means (for each plant species) with different letters are significantly different at $p<0.05$ according to Tukey's HSD test. ***: $p<0.001$, *: $p<0.05$, ns: not significant (i.e., $p>0.05$ ), df: degrees of freedom 
Phenolic compounds have been known in plant defense mechanisms against abiotic stresses such as heavy metal toxicity and to biotic stresses such as phytopathogenic fungi and bacteria in several plants (Singh and Agrawal, 2010; Daayf et al., 2012; ElBebany et al., 2013). Thus, diminishing phenol content in plants grown in soil amended with SS may inhibit their resistance to pathogens.

\section{Conclusions}

The current investigation assessed the biochemical parameters in four crops (faba bean, wheat, spinach and cucumber) cultivated in agriculture soil amended with SS. The results revealed that the response at the biochemical level is differing according to the plant species and SS application rate. In spinach, starch was decreased significantly with SS treatments, whereas, increased in faba bean, wheat and cucumber at 10, 20, 30 and $40 \mathrm{~g} / \mathrm{kg} \mathrm{SS}$ amendment rates. The concentrations of water soluble carbohydrates and total non-structural carbohydrates were declined in all the tested plants as response to SS amendments. Total lipids were increased in all plants depend on the SS application rates. The increase of total lipids started at $20 \mathrm{~g} / \mathrm{kg} \mathrm{SS}$ treatment in faba bean and spinach, whereas, at 40 and $50 \mathrm{~g} / \mathrm{kg} \mathrm{SS}$ amendments in wheat and cucumber. The amino acid proline accumulated significantly in spinach, wheat and cucumber at all SS treatment rates, while the changes were not significant in faba bean. There were no significant differences in phenol content in faba bean and spinach. The phenol content was decreased in wheat and cucumber leaves with SS treatment. Application of SS to agricultural soils alters the chemical composition of crops. The application of SS at low amendment rates from 10 to $40 \mathrm{~g} / \mathrm{kg}$ could be useful, whereas, the highest amendment rate, i.e. $50 \mathrm{~g} / \mathrm{kg}$ is not recommended because of the negative effects on the biochemical composition of the plant, in addition to the possible accumulation of heavy metals in plant materials that may be used for human food or animal feed. The SS amendments could be oriented according to the crop consuming purposes. Future experiments on successive applications of SS in agricultural sites are needed to explore the long-term effects of SS on crops.

Acknowledgements. This work was supported by the Deanship of Scientific Research at King Khalid University under Grant number R.G.P. 1/73/40.

\section{REFERENCES}

[1] Abdel Latef, A. A. H., Sallam, M. M. (2015): Changes in growth and some biochemical parameters of maize plants irrigated with sewage water. - Austin J Plant Biol. 1: 1004.

[2] Abdul Khaliq, S. J., Al-Busaidi, A., Ahmed, M., Al-Wardy, M., Agrama, H., Choudri, B. S. (2017): The effect of municipal sewage sludge on the quality of soil and crops. - Int J Recycl Org Waste Agricult. 6: 289-299.

[3] Ahmed, H. K., Fawy, H. A., Abdel-Hady, E. S. (2010): Study of sewage sludge use in agriculture and its effect on plant and soil. - Agric Biol J N Am. 1: 1044-1049.

[4] Asgharipour, M. R., Khatamipour, M., Razavi-Omrani, M. (2011): Phytotoxicity of cadmium on seed germination, early growth, proline and carbohydrate content in two wheat verities. - Adv Environ Biol. 5: 559-565.

[5] Bates, L. S., Waldran, R. P., Teare, I. D. (1973): Rapid determination of proline for water stress studies. - Plant Soil 39: 205-207. 
[6] Belhaj, D., Elloumi, N., Jerbi, B., Zouari, M., Abdallah, F. B., Ayadi, H., Kallel, M. (2016): Effects of sewage sludge fertilizer on heavy metal accumulation and consequent responses of sunflower (Helianthus annuus). - Environ Sci Pollut Res. 23: 20168-20177.

[7] Boudjabi, S., Kribaa, M., Chenchouni, H. (2015): Growth, physiology and yield of durum wheat (Triticum durum) treated with sewage sludge under water stress conditions. EXCLI J. 14: 320-334.

[8] Bourioug, M., Alaoui-Sossé, L., Laffray, X., Raouf, N., Benbrahim, M., Badot, P.-M., Alaoui-Sossé, B. (2014): Evaluation of sewage sludge effects on soil properties, plant growth, mineral nutrition state, and heavy metal distribution in European larch seedlings (Larix decidua). - Arab J Sci Eng. 39: 5325-5335.

[9] Bray, H. G., Thorpe, W. V. (1954): Analysis of phenolic compounds of interest in metabolism. - Methods Biochem Anal. 1: 27-52.

[10] Byreddy, A. R., Gupta, A., Barrow, C. J., Puri, M. (2016): A quick colorimetric method for total lipid quantification in microalgae. - J Microbiol Methods 125: 28-32.

[11] Daayf, F., El Hadrami, A., El-Bebany, A. F., Henriquez, M. A., Yao, Z., Derksen, H., El Hadrami, I., Adam, L. R. (2012): Phenolic Compounds in Plant Defense and Pathogen Counter-Defense Mechanisms. - In: Cheynier V., Sarni-Manchado, P., Quideau S. (eds.) Recent Advances in Polyphenols Research. Vol. 3. Wiley-Blackwell, Oxford, UK, pp. 191-208.

[12] Dhir, B., Sharmila, P., Saradhi, P. P. (2004): Hydrophytes lack potential to exhibit cadmium stress induced enhancement in lipid peroxidation and accumulation of proline. Aquat Toxicol. 66: 141-147.

[13] Eid, E. M., El-Bebany, A. F., Alrumman, S. A., Hesham, A., Taher, M. A., Fawy, K. F. (2017a): Effects of different sewage sludge applications on heavy metal accumulation, growth and yield of spinach (Spinacia oleracea L.). - Int J Phytoremediat. 19: 340-347.

[14] Eid, E. M., Alrumman, S. A., El-Bebany, A. F., Hesham, A., Taher, M. A., Fawy, K. F. (2017b): The effects of different sewage sludge amendment rates on the heavy metal bioaccumulation, growth and biomass of cucumbers (Cucumis sativus L.). - Environ Sci Pollut Res. 24: 16371-16382.

[15] Eid, E. M., Alrumman, S. A., El-Bebany, A. F., Fawy, K. F., Taher, M. A., Hesham, A., El-Shaboury, G. A., Ahmed, M. T. (2018): The evaluation of sewage sludge application as a fertilizer for broad bean (Faba sativa Bernh.) crops. - Food Energ Secur. 7: e00142.

[16] Eid, E. M., Alrumman, S. A., El-Bebany, A. F., Fawy, K. F., Taher, M. A., Hesham, A., El-Shaboury, G. A., Ahmed, M. T. (2019): Evaluation of the potential of sewage sludge as a valuable fertilizer for wheat (Triticum aestivum L.) crops. - Environ Sci Pollut Res. 26: 392-401.

[17] Eid, E. M., Shaltout, K. H., Abdallah, S. M., Galal, T. M., El-Bebany, A. F., Sewelam, N. A. (2020a): Uptake prediction of ten heavy metals by Eruca sativa Mill. cultivated in soils amended with sewage sludge. - Bull Environ Contam Toxicol. 104: 134-143.

[18] Eid, E. M., El-Bebany, A. F., Taher, M. A., Alrumman, S. A., Hussain, A. A., Galal, T. M., Shaltout, K. H., Sewelam, N. A., Ahmed, M. T., El-Shaboury, G. A. (2020b): Influences of sewage sludge-amended soil on heavy metal accumulation, growth and yield of rocket plant (Eruca sativa). - Appl Ecol Environ Res. 18: 3027-3040.

[19] El-Bebany, A. F., Adam, L. R., Daayf, F. (2013): Differential accumulation of phenolic compounds in potato in response to weakly and highly aggressive isolates of Verticillium dahliae. - Can J Plant Pathol. 35: 232-240.

[20] Elloumi, N., Belhaj, D., Jerbi, B., Zouari, M., Kallel, M. (2016): Effects of sewage sludge on bio-accumulation of heavy metals in tomato seedlings. - Span J Agric Res. 14: e0807.

[21] El-Maghraby, S. S., Gomaa, M. A. (1992): Effect of sewage sludge as a fertilizer on syrup yield and some agronomic characters of sweet sorghum. - Egypt J Appl Sci. 7: 300-317.

[22] Granéli, W., Weisner, S. E. B., Sytsma, M. D. (1992): Rhizome dynamics and resource storage in Phragmites australis. - Wetland Ecol Manag. 1: 239-247. 
[23] Han, S.-H., Lee, J.-C., Jang, S.-S., Kim, P.-G. (2004): Composted sewage sludge can improve the physiological properties of Betula schmidtii grown in tailings. - J Plant Biol. 47: 99-104.

[24] Hue, N. V. (1988): Residual effects of sewage-sludge application on plant and soil-profile chemical composition. - Commun Soil Sci Plant Anal. 19: 1633-1643.

[25] John, R., Ahmad, P., Gadgil, K., Sharma, S. (2009): Heavy metal toxicity: Effect on plant growth, biochemical parameters and metal accumulation by Brassica juncea $\mathrm{L}$. - Int $\mathrm{J}$ Plant Prod. 3: 65-76.

[26] Kabata-Pendias, A. (2011): Trace Elements in Soils and Plants. - CRC Press, Boca Raton, FL.

[27] Kępka, W., Antonkiewicz, J., Jasiewicz, C., Gambuś, F., Witkowicz, R. (2016): The effect of municipal sewage sludge on the chemical composition of spring barley. - Soil Sci Annual 67: 124-130.

[28] Mazen, A., Faheed, F. A., Ahmed, A. F. (2010): Study of potential impacts of using sewage sludge in the amendment of desert reclaimed soil on wheat and Jews mallow plants. - Braz Arch Biol Technol. 53: 917-930.

[29] Sharma, B., Kothari, R., Singh, R. P. (2018): Growth performance, metal accumulation and biochemical responses of Palak (Beta vulgaris L. var. Allgreen H-1) grown on soil amended with sewage sludge-fly ash mixtures. - Environ Sci Pollut Res. 25: 1261912640.

[30] Singh, R. P., Agrawal, M. (2008): Potential benefits and risks of land application of sewage sludge. - Waste Manag. 28: 347-358.

[31] Singh, R. P., Agrawal, M. (2010): Biochemical and physiological responses of rice (Oryza sativa L.) grown on different sewage sludge amendments rates. - Bull Environ Contam Toxicol. 84: 606-612.

[32] Smith, D., Paulsen, G. M., Raguse, C. A. (1964): Extraction of total available carbohydrates from grass and legume tissue. - Plant Physiol. 39: 960-962.

[33] Statsoft. (2007): Statistica Version 7.1. - Statsoft Inc., Tulsa, OK.

[34] Tantrey, M. S., Agnihotri, R. K. (2010): Chlorophyll and proline content of gram (Cicer arietinum L.) under cadmium and mercury treatments. - Res J Agricul Sci. 1: 119-122.

[35] Tripathi, A. K., Tripathi, S. (1999): Changes in some physiological and biochemical characters in Albizia lebbek as bioindicators of heavy metal toxicity. - J Environ Biol. 20: 93-98.

[36] Wyrwicka, A., Urbaniak, M. (2016): The different physiological and antioxidative responses of zucchini and cucumber to sewage sludge application. - PLoS ONE 11: e0157782.

[37] Zeid, I. M., Abou El Ghate, H. M. (2007): Effect of sewage water on growth, metabolism and yield of bean. $-\mathrm{J}$ Biol Sci. 7: 34-40. 